\title{
ASPECTS OF EVERYDAY LIFE IN THE OLD-BULGARIAN HAGIOGRAPHICAL CYCLE OF STORIES $A$ TALE OF THE IRON CROSS
}

\author{
Y. M. Hristov, N. Hrissimov
}

Христов Я. М., Хрисимов Н. Аспекти от всекидневния живот в старобългарския агиографски цикъл „Сказание за железния кръст“. Агиографският цикъл от разкази-чудеса, известен под названието „Сказание за железния кръст“, е сравнително добре познат в научните среди. Въпреки това, все още не може да се каже, че е проучен напълно като исторически извор. Подобен факт е до голяма степен изненадващ. Дори и бегъл поглед върху фрагментите от текста предоставя възможност за открояване на редица аспекти от всекидневния живот в новопокръстена България. Забелязват се описания на облекло, храни и напитки, а също така и на някои стопански занимания. Наред с това има регистрирани и различни заболявания, причини за здравословни проблеми и методи на лечение. Подобни детайли в старобългарския агиографски цикъл са от съществено значение, особено ако се отчете сравнително ограничения набор сведения за всекидневния живот на популярно равнище в началните етапи от изграждане на т. нар. Slavia Orthodoxa.

Ключови думи: агиография; всекидневие; облекло; храни; напитки.

Христов Я. М., Хрисимов Н. Аспекты повседневной жизни в староболгарском агиографическом цикле «Сказание о железном кресте». Агиографический цикл, состоящий из рассказов-чудес, именуемый «Сказание о железном кресте», сравнително хорошо известен в научной среде. Несмотря на это все еще нельзя сказать, что он полностью изучен как исторический источник. Подобное утверждение может показаться неожиданным. Но даже беглый взгляд на фрагменты текста представляет возможность отчетливо выделить ряд аспектов повседневной жизни в только что крещенной Болгарии. Обращают на себя внимание описания одежды, еды и напитков, а также и некоторые хозяйственные занятия. Вместе с тем зафиксированы различные заболевания, причины медицинских проблем и способы лечения. Подобного рода детали в староболгарском агиографическом цикле имеют большое значение, имея в виду сравнительно ограниченный набор сведений о повседневной жизни населения в начале строительства т. н. Slavia Orthodoxa.

Ключевые слова: агиография; повседневность; одежда; еда; напитки.

Hristov Y. M., Hrissimov N. Aspects of everyday life in Old-Bulgarian hagiographical cycle of stories $\boldsymbol{A}$ Tale of the Iron Cross. The hagiographical cycle of stories - A Tale of the Iron Cross is relatively well-known, but as a source of information for everyday life it still has not been studied properly. Such a fact is somewhat surprising. Even a glimpse at Tale's texts gives an opportunity many questionable aspects of daily life to be shown. A serious look at the cycle's data is very fruitful. There are some important descriptions of clothes, foodstuff, drinks consummation as well as craft activities. Moreover, records concerning various types of illnesses, reasons of health disorder and treatment skills also can be observed. At the same time the importance of those features increases when scholars take into consideration the historical database which left unknown many sides of daily life in the dawn of so-called Slavia Orthodoxa.

Keywords: hagiography; everyday life; clothes; food; drinks.

When we talk about the Old Bulgarian cycle of stories named A Tale of the Iron Cross, it must be acknowledged that it is relatively known but it still looks as if there are enough things to add. This medieval literary work has a complex structure. A Tale of the Iron Cross is a macrocomposition that incorporates ten stories dedicated to Saint George - 1. About the priest's son; 2. About the child; 3. About the monk; 4. About the cross and the Bulgarian (also known as The Miracle of Saint George with a Bulgarian warrior); 5. About the woman; 6. About the furious teenager; 7. About the shepherd bitten by a snake; 8. About the man with a leg injury; 9. About Kliment who was saved by St. George in war; 10. About the woman having breast wound. These miracle-stories are framed by a preface and a closing part ${ }^{1}$. The first critical survey which concerns the whole hagiographical cycle was made by the Bulgarian scientist B. St. Angelov in the 
$1970 \mathrm{~s}^{2}$. But it must be put on record that at least one of the Tale's copies was observed quite early in the middle of the nineteenth century. Such activity was limited. Primarily, it concerns only registration of mentioned literary work within Old Slavonic manuscripts. Nevertheless, the huge stratus of historical data was a reason to start using as a source of information the so-called story The Miracle of Saint George with a Bulgarian warrior - definitely the most famous part of the whole hagiographical cycle ${ }^{3}$. This text raises huge prestige among the scientists and it is widely and continuously exploited in the studies of the late $9^{\text {th }}$ century Bulgarian history. Due to that, some kind of investigational habit has been made, and in addition supplemented by a little dose of inertness in the perception and usage of the Tale's stories. Since the $19^{\text {th }}$ century onwards the benevolent attitude to The Miracle of Saint George with a Bulgarian warrior goes with some kind of neglect to the rest of the cycle $A$ Tale of the Iron Cross. Reasons for the outlined underestimation are patchwork of objective and subjective figures. Until 1970s the first ones could be assumed as prevalent. For the following decades the predominance of the second group must be admitted. However, the scientific interest increases gradually. It has been extended to several main research directions: they depend on the Tale's origin as a whole literary work and separate stories or on the personality of the writer, his literary fictions and linguistic peculiarities and finally, but with high importance, the value of the miracle stories as a source of diverse information for the late $9^{\text {th }}$ - early $10^{\text {th }}$ centuries ${ }^{4}$.

At the present stage, it is abundantly clear that the most prominent and steady research activities concerning the regarded hagiographical cycle are performed by the Russian scientist Anatoliy A. Turilov. In his works it is sought to justify the answers to the questions when, how, why and by whom the work was written by marking the political and cultural situation. The name of the medieval author (compiler) - monk Christodoulos (with a very probable Greek origin), who composed the macro-composition, also became known in the scientific community through the efforts of the mentioned researcher ${ }^{5}$. It is he again who noted that the miracles of the Fourth (About the cross and the Bulgarian) to the Tenth (About the woman) were part of the original Old Bulgarian prose and the first three stories of the popular today numbering of the cycle are the obvious Byzantine layers in the Tale. The respective circumstance did not represent an important barrier for the major part of today's known version of the text having an Old Bulgarian origin, to have existed and circulated on the popular level in oral form. The compiling of the Tale itself is an illustration of how the writings that appeared in the Bulgarian milieu and processed in literary Old Bulgarian are supplemented and compiled together with Greek texts during the cultural dialogue among ethnic groups in the Byzantine-Slavic world 6 .

In fact, distrust traced in the opposition "domestic - translated" is even counterproductive. It should not be forgotten that in the early stages of the development of the Old Bulgarian literature for scholars of Preslav's circle, the knowledge of the Byzantine art samples and copying them is combined with a more relaxed attitude to the source. Meanwhile, the Byzantine texts are used as a role model to follow when creating home works, as in what is translated as well as created, domestic authors often blur the boundary between this part of the works that is a result of their creative genius and the one that is borrowed ${ }^{7}$.

The presence of translated and original Old Bulgarian passages within today's known version of $A$ Tale of the Iron Cross cannot be a justifiable obstacle to its use as a complete historical source. Thanks to the abundance of diverse information, the Old Bulgarian cycle allows the look at the sources of the author-compiler and adds touches around its erudition or proceeds with the reconstruction of still sporadically affected in the Bulgarian medieval studies issues relating to illnesses and treating them ${ }^{8}$. In efforts for the reconstruction of knowledge, skills, habits or principles of social behavior, the probable presence of unreal, imaginary characters in the fragments of the text is not highly important, because all Tale's stories display selected examples and depict the development of the recently baptized Bulgarian society during the late $9^{\text {th }}$ and the beginning 
of the $10^{\text {th }}$ century. When the fact that the reported data concern the Early Middle ages is taken into consideration, such a specificity of the observed hagiographical literary work increases its significance.

Successfully disguised by the indisputable advantages of $A$ Tale of the Iron Cross as a literary work of art and as a complete historical source, there hardly stands out an interesting specificity that from today's perspective can be perceived as a disadvantage. It is expressed in the fact that in the fragments of the studied written record, a number of elements of the everyday life such as housing, heating, lighting, furniture, food and beverages and flavors are just slightly marked or as a whole they are very vaguely mentioned in the text. In this connection, it is not superfluous to add that today the familiar version of the cycle of miracle stories, without conditionalities and caveats, there is presented only one case of use of drinking water. „И рєчє старєць: Почєрпи вод,ьы,

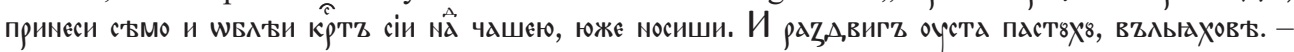
notes the compiler Christodoulos in the Seventh miracle where there is a description of saving the snakebitten shepherd, adding a few lines below - И въємZ, шьліи во,А, ю10, А,джь очнА,А,єномв пити

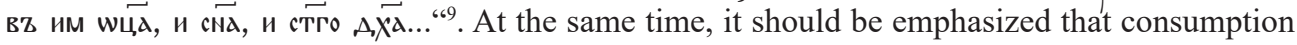
of fluids is mentioned in the First and Second one and to a certain extent in the Ninth miracles. Compared to the first two it is related to the use of the drinks wпсимz and очкропz. Both drinks have reasons to be considered with alcoholic content. While for ovkponz doubts seem to have less explicitness. Some of Church Slavonic (Old-Bulgarian) dictionaries refer that one of the main meanings of oүкропz is warm/hot water. Besides, interesting interpretation has been given to the meaning of ovкропz in Ostromir Gospels. It is about the so called „теплота“ (warmth) - a term known from church practice. ${ }^{10}$ It indicates the warm water poured with a special vessel towards the wine for Holy Communion. In this way, there is symbolism with the warm blood that flowed from the body of Christ at the Crucifixion ${ }^{11}$. Along with this, in the analyzed text of $A$ Tale of the Iron Cross, it is also stated that the prepared drink is flavoured with cumin. Some indication of what is meant by oykponz in Slavonic milieu comes from the fact that in the translated texts the lexical unit is in the place where the Greek original mentions that wine is "mixed with drinking water" (in some cases there has been added honey, too) ${ }^{12}$. One can say that within the frames of A Tale of the Iron Cross it is about warmed up or boiled over wine with spices. The case with шпсим appears to be a real challenge. Looking inside, within the context, the use of the lexical unit, it is clearly outlined that it was something out of the ordinary, not merely preheated water, but it can rather be said that it is used to compare a beverage having such a "stinging" or "burning" characteristic feature. Too eloquent in this respect is one part of the Tale's second miracle - About the child ${ }^{13}$. This again points to searching some kind of alcoholic beverage, but as if with a higher degree than the wine to create a burning sensation. With a substantive dose of caution it can be presumed that in this case described in one of Tale's compiled part (maybe) the drink шпсимz is related to the famous from later time Arak (or Anisette/Mastic). Given the appearance of the drink in the First miracle, which has undisputed Byzantine origin, there may be made an interpretation in the direction of its Byzantine origin, and calling it with a Slavic name - its use in the Bulgarian setting as well. Worries over a more categorical determination of шпсимz for some early distillate, predecessor of Arab arak, come from a relatively early stage of the drafting of the Tale - to the first decade of the tenth century. On the other hand, references of that drink within the context of the macro-composition of miracle stories do not "leave" the early compiled and translated passages and emphatically point precisely at the use in the Arab surroundings ${ }^{14}$.

Given the context, in various stories, using the lexical units ,пиво“ and „пите/питин“", it becomes clear that there is no reference to water ${ }^{15}$. The latter one, of course, does not mean that judging by the source that is being discussed in the late $9^{\text {th }}$ and the beginning of the $10^{\text {th }}$ century in the Bulgarian lands people suffer from thirst or water is consumed in much smaller extent at the expense of other drinks. What is even more indicative is that in several described moments 
of eating there is no bread, vegetable products or wine. It could be said that some details about the food composition are only present in korban rites, while in The Miracle of Saint George with a Bulgarian warrior, in the transcripts extensive editing, the pejorative definition of ,, врашьно" can also be found ${ }^{16}$. In describing the feast before the second campaign against the

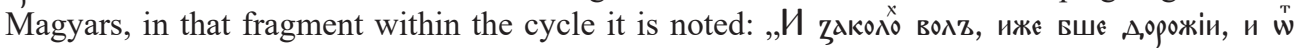

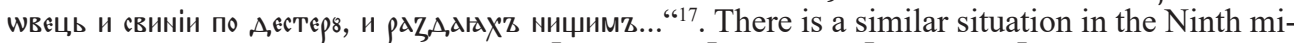

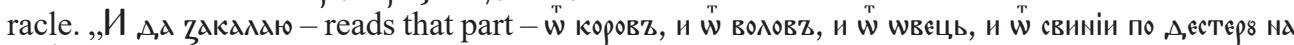
${ }_{,}, \widetilde{\mathrm{Nb}}$ твон“. In the rest of the passages it is spoken about ,

The described feast before the Bulgarian warrior George made for in the second campaign against the Magyars, generally defined him as a person holding a large stock breeding estate ${ }^{19}$. However, it should be emphasized that any conclusions on economic commitments and economic initiatives based solely on the comment of korban rites in A Tale of the Iron Cross, are highly hypothetical and destined to remain mere assumptions. The grounds for such a claim are rooted in the information in the miracle stories. Therefore, the researchers are willing to accept that with these records the medieval scholar outlines scenes from the functioning of an established cult, illustrating the operation of the system "a gift for a gift".

The opinion of the religious workload and various forms of voluntary sacrifice in the macrocomposition is shared by Bulgarian and foreign scientists ${ }^{20}$. Interestingly, in some cases, the main focus in the interpretation of the sacrifice in A Tale of the Iron Cross is aimed at the Ninth miracle - About Kliment, who was saved by St. George in war. Despite the large volume, the specific historical information in that fragment of hagiographic cycle is more modest compared with the thematically and symbolically tied with it story about the miracle with warrior George. Indeed, viewed through the prism of political history, the text of About Kliment who was saved by St. George in war itself looks as though it is not always able to elicit a particular interest. In tracing the connections between the two mentioned fragments of the macro-composition N. Dragova tends to see in them features of the life of certain strata in the newly baptized society associated with pre-Christian traditions that are still part of the life of the population even after the conversion. The main motivation is related to the registration in the cycle of a situation with no shared knowledge (or skill), locked or unknown in origin and mode of action for the other members of society, through the mystery of it, with which the ones applying it are related. The taboo over skills and knowledge acquired during the transition from one stage of life to another or changing the social status are associated with initiation in pagan religions. The repercussions of such an action after Christianization, followed by the power of tradition, are found in the abovementioned stories from $A$ Tale of the Iron Cross ${ }^{21}$.

However, it is reasonable to emphasize that the moments in the cycle reminding pagan practices are "cut" from a highly Christianized stream and are disguised as miracles - no doubt as a result of repeated revisions of the works in their recording and rewriting. At the same time, one should take into account the fact that in the post-conversion period of time, the popular culture (largely resting on tradition), seeks its place in the new Christian framework of society. In this regard, community groups committed to promoting religious change are often forced to take compromising decisions as well, by which they trace and channel ways and means of entry of resistant relicts proven their vitality. Huge is the likelihood that this decision is implemented by the compiler of $A$ Tale of the Iron Cross.

In today's known version of the hagiographic cycle it is mentioned that the Bulgarian warrior Kliment organizes an annual table with ritual sacrifice, without telling anyone that this is part of an agreement with his transcendental patron - St. George. The separate feast of poor, landless, homeless and clergy is a reminiscence of pagan practices, depicted by the passage ,П Првыи А,

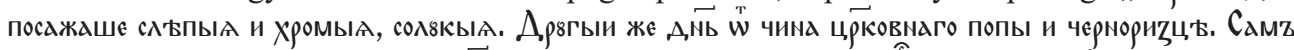

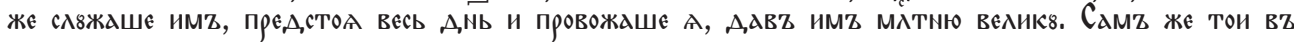




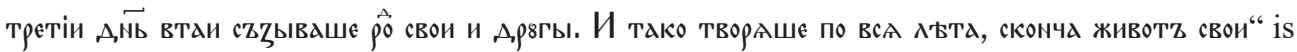
seen as a consequence of the relationship between the dedicated warriors and those unfit for war - poor, lame and priests ${ }^{22}$. This part of the text of the Ninth miracle in the macro composition is perceived as a reflection of the opposition sufficiency-inferiority, i.e. distinction of "carriers of the characterization and carriers of the non-characterization". It is this opposition to insiders and outsiders within the Old Bulgarian hagiographic cycle according to N. Dragova that allows restoring a rite of the male warrior's initiation ${ }^{23}$.

Such an interpretation of the text is more than possible, especially when correlated to the information in the miracle story of George, where the taboo also excludes the warrior's wife and the blacksmith, but it does not apply to associates of the military squad ${ }^{24}$. When commenting on the Tale in the direction outlined, it is necessary to take into account that the stories even in the pagan primary source are subjected to the influence of a modeling and unifying treatment on behalf of a writer Christian (more than likely a cleric). The motive for the distribution of the assets of the poor and the clergy, having in mind its editorial intervention, is certainly reasonable to be seen as part of the Christianized stream in recording and disseminating an oral warrior tale as an already hagiographic work. Thus, even if it is traditionally (before Christ) set, the opposition "fitness - unfitness" was placed under the new religious worldview and the total audience is recognizable as an example of Christian behavior and morality.

Here we should mention that fathers' pagan relics and folklore-mythological layers as far as they are present in the Old Bulgarian cycle, attract the attention of other scientists. T. Mollov has a different approach towards the commentary of the sacrifices in the Tale of the Iron Cross. For him they are linked to the overall soteriological aspect of the work. In this connection, saving the doomed warrior out of the stalemate in which he falls into is a key point. It evokes in the baptized former pagan a responding ritual practice, which must comply with the imposed Christian conception of life and death. ${ }^{25}$ At the same time, the mentioned scholar notes that the services and feasts in the Tale do not need to be understood solely as a gesture of gratitude towards the saint advocate. They can also be interpreted as an act of replacing a man with a prey that is a domestic animal (animals), which is equivalent to him $^{26}$. That demonstrates the developed since pre-Christian time tradition in the Bulgarian society to make sacrifices and the fact that it continues to exist in the late $9^{\text {th }}$ and the beginning of the $10^{\text {th }}$ century. At the time of its registration in the pages of $A$ Tale of the Iron Cross, however, this practice has two clearly discernible traits. According to the first one, it is perceived as part of the Christian rituals and behavior at a popular level. According to the second characteristic, whether the korban rite is intended to be a personal or massive one, it is imperatively connected with the public and shared with other members of society ${ }^{27}$.

In interpreting the aforementioned passages in the Old Bulgarian cycle of miracle stories the comments N. Barabanov are especially productive. He expressly states that in the early Byzantine era, the Eastern Christian community developed a principle for response towards the corresponding pagan sacrifice. The church's stance on the korban rites in earlier periods is characterized by a kind of inertia, as the pagan sacrifices are opposed to Christian ones, combined with inconsistent attempts by senior clergy to proceed with the ban on such actions. The reasons are more than understandable. As it is known, animal sacrifice, no matter if it is group or individual, public or private, is among the most representative pre-Christian religious specificities in the Mediterranean and its adjacent regions. In the early Christian era, troubled by pagan parallels, clergy did not recognize the sacrificial ceremonies in the number of official practices and seeks to depart them from the temples. At the same time, the alignment of the interests of the clergy and the congregation requires coming to terms with certain permitted "uncanonical nature" of the korban rite because of the piety of the venture. So the church itself, to a significant extent, contributes to the rooting of the sacrificial slaughter of domestic animals, for religious reasons, at a popular level in the 
Byzantine-Orthodox world. Gradually, over time, the ritual is detached from its pagan prototype and is reconsidered using ancient and evangelical examples in the spirit of Christianity ${ }^{28}$.

After accounting for these characteristics in terms of sacrifices in the newly converted Bulgarian society at the end of the $9^{\text {th }}$ century and the first decades of the $10^{\text {th }}$ century, one can say that for the compiler of the macro-composition and his audience there is no conflict between the new and old religious practice. As an action and over meaningful workload, in nature and as intended, the two overlap to a considerable extent. Even when trying to see in them residues of an initiation ritual, their apparent Christian reconsideration is recognized. A fact that does not cause astonishment after taking into account that it is registered on the pages of the Christian on focus and purpose work.

As for the aspects of the everyday life on a popular level, examples can be expanded with furniture, rugs and clothing. Options for their detailed registration in the Tale exist repeatedly. In describing the sick monk in the third story About the monk, during the presentation of life in retreat in the reviewed About the shepherd bitten by a snake or any subsequent About the man with a leg injury and About the woman having breast wound. Particularly suitable in that direction is the fourth miracle story of the cycle. In its text there is a passage that reads: „И лєжацю

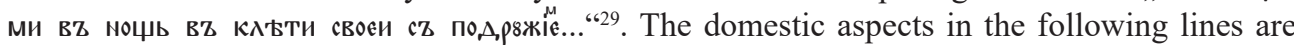
saved to give way to the main creative design - presenting the wonders and signs of St. George:

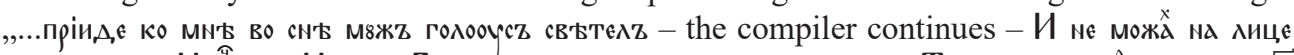

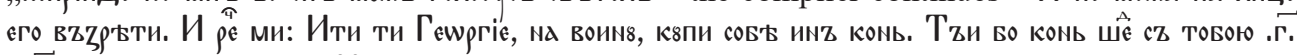

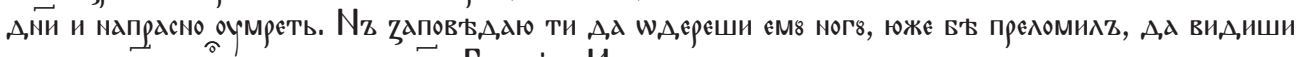

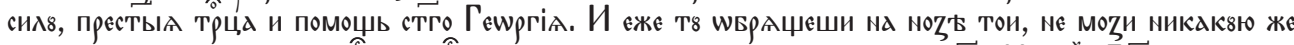

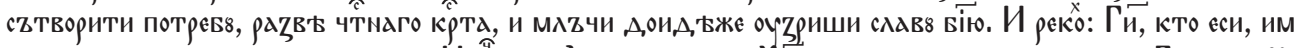

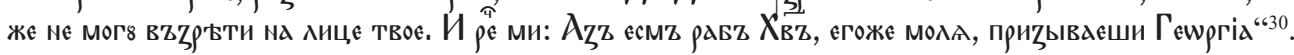

It is also interesting to note that the pages of the concerned hagiographic cycle practically lack colors. The principle of their omission is violated vaguely by their one and only marking in "bloody froth" in the Second miracle. The silence in terms of colors in the fragments of the macro-composition would be total if the writer's view of the compiler does not consider that black and white are worthy of mentioning. Here, however, it should be emphasized that the vast majority of their registrations in the texts refer to the miraculous interventions of St. George. The study of the language features of the hagiographic cycle notes that ,Мжжz (м8жь in the text - sine

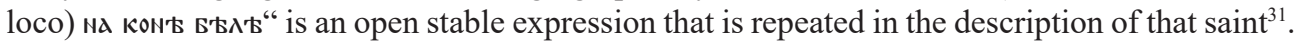
Alternating мжжz with мжжз оунz and юноша does not affect the fact that mentioning the white color is accompanied by the actions of the saint. It is in the Sixth miracle where besides riding a

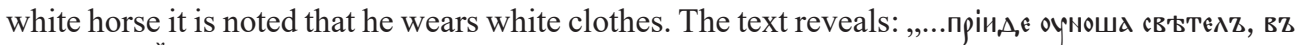
Б'хлахz риzа...."32. There is a similar situation with the other fragments of the macro-composition as the Seventh, Ninth and Tenth miracles. According to the records in them, normally, but not necessarily, the saint appeared in their sleep ${ }^{33}$. The mentioned detail acquires sound, if one goes slightly off line, for a very significant Byzantine influence in drafting the hagiographic cycle. The role of the Greek vocabulary and artistic models is more than apparent. Moreover, recently K. A. Maksimovic again focuses on tracking techniques applied in the translation from Latin in the circle of Cyril and Methodius students, which can be very productive in the study of

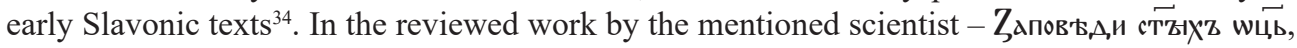
for whose closest original is considered Poenatentiale Mersenburgense, the correspondence of monachus (monk) draws attention, translated as чрьмориз єць and laicus (layman) - translated as Бълоридєць. The designated examples are direct parallels in the Eucholgium Sinaiticum as at a relatively early stage, there is a tendency to use shorter forms чрьмьць, instead оf чрьморибєць and accordingly въ be noted that in the Tale, St. George is presented very clearly as a young rider in secular clothing. 
Generally, a sequence can be noticed in the registration of the black color. It is again used persistently to express a particular social status and presentation of individuals associated with it. Within the hagiographic cycle, black is used to describe monasticism and monks. As here there

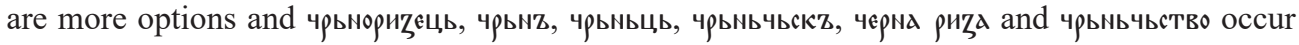
repeatedly in the identified as Old Bulgarian, originally author's parts of the cycle.

The compiler Christodoulos is similarly frugal in terms of detail, both with colors and while presenting information about clothing, although the initial stories from the cycle create a different impression. It is necessary to point out, however, that the first three miracles are in the translated and compiled layers of A Tale of the Iron Cross. As a result, the story About the priest's son recreates the popular Byzantine hagiography scheme for relief from foreign captivity applied

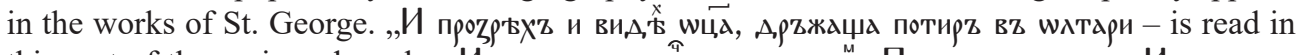

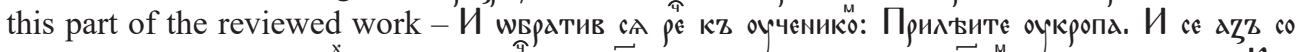

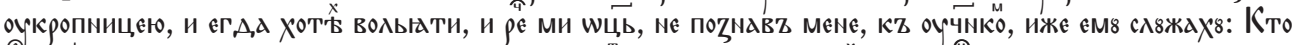

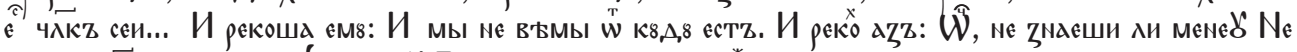

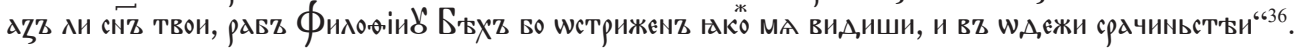
For the current presentation it is more important that the saved one is quite reasonably dressed in a costume typical of the country where he resided as a prisoner. That clue seems to be the most detailed registration of clothing throughout the whole hagiographic cycle. If we do not count

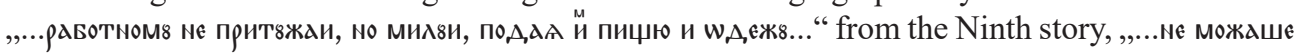

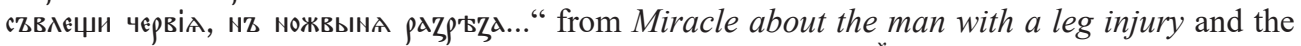

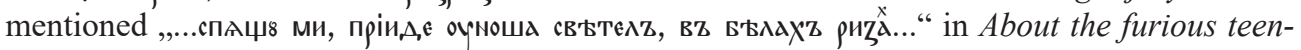
ager, the other updates are of the same character for the monks - black-coated ${ }^{37}$.

When commenting clothes' elements or features of the costume in Early Mediaeval Bulgaria, unfortunately, it must be recognized that the soils on the territory of the First Bulgarian Kingdom are too acidic and not conducive to the preservation of organic materials, such as textiles and therefore, we have no direct data about clothing; here we include colorful characteristics of the population as well. In this regard, of no help are the preserved miniatures, which traditionally depict members of aristocratic circles, whose clothes are characteristic bright colors ${ }^{38}$. In this situation, analogies can be made up with the clothing of nations from North Caucasus and in particular Alans who, in lifestyle and level of cultural development, have that of the Bulgarian territories during the period. Cloths found in the Alans cemeteries are very well preserved and give a good idea about the coloring of the garments worn by them. The pivot tables presented by Z. Dode, giving valuable information on the exposed parts of clothing contain information about their color, but in a modern state. All preserved remnants of clothing are described with the following colors: brown, beige, gray-white, off-white, dark gray, brownish, light brown, gray, etc. ${ }^{39}$ Given the remoteness of the time they are made and all natural conditions they were exposed to, plus the range of colors, which describes their current condition, one can with a great deal of confidence assume that their original color was white. This coincidence with the basic color of the clothing well illustrates that in the ethnic groups similar to Bulgarians, the most common clothing color is white.

Despite the lack of words and phrases related to the description of the colors and details regarding clothing, it must be stressed that the aspects of everyday life, involved in drafting the Tale are the cause to mention some metals, raw materials, crafts and craft production. One of the highlights is linked to information about business practices in a part of the lands in the Eastern Sub-Balkan during the period the hagiographic cycle appeared - initial decades - two of the $10^{\text {th }}$ century $^{40}$. The movement of goods in About the shepherd bitten by a snake is outlined clearly. The first illustrates that the cattle taken to grazing is subject to sale, which is obviously one of the reasons to be raised. The information corresponds to the passage in the Fourth miracle that also talks about buying and selling animals and hints at the existence of markets in the provinces ${ }^{41}$. 
The second case of trading goods in the story About the shepherd bitten by a snake is also

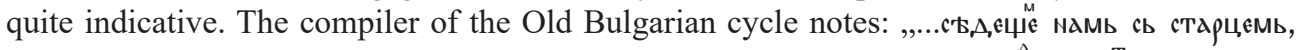

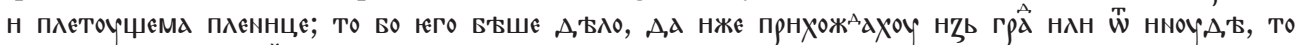

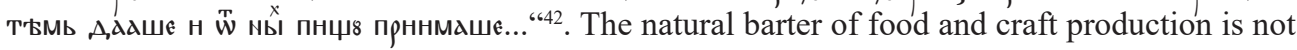
surprising at all. The notice overlaps entirely with the knowledge of the economic characteristics of societies in the Eastern Balkans during the early Middle Ages. At the same time, the exercise of certain activities, for personal salvation or livelihood, is in line with the emerging trends among Eastern Christian monasticism in the world during that period. The described in the Tale forms of spiritual coaching and life in relative seclusion, but without losing the connection to the surrounding population, fit into the testified in narrative, epigraphic and archaeological way monastic practices in the First Bulgarian State at the beginning and middle of the $10^{\text {th }}$ century ${ }^{43}$.

Even in the early stories of the hagiographic cycle there are registered the presence and use in everyday life of containers for liquids made of glass. Such information is related to the famous for craft industries in Pliska and Preslav in the late $9^{\text {th }}-10^{\text {th }}$ century. The two capitals are centers of economic life, usually concentrated in industrial complexes, away from inhabited areas. Among the activities performed requiring high specialization is glass industry, as in both capitals, there are open workshops for the manufacture of glass. The open workshops with numerous smelters, and the found in them production and waste of window glass and glass vessels, strongly suggest that, at least within the government center, glass products are not strange ${ }^{44}$. Here especially, it is needed to pay attention to the fact that glass vessels are found only in the workshop in Preslav, while such are not found in Pliska's workshop. While considering the mentioned feature, it is clear why the repeated references to the jar in the First miracle About the priest's son are

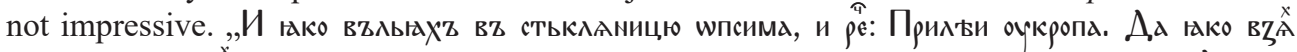
очкропницю, мач

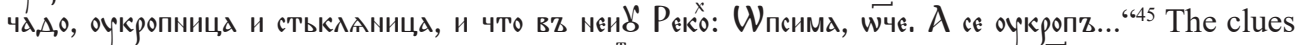
of this kind in the text continue with: ,...И $\underset{w}{w}$ страха и жалости въстрєпета шць мои, очпвстити

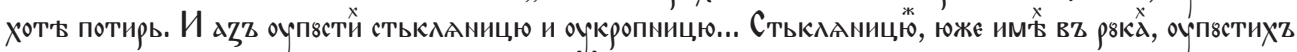

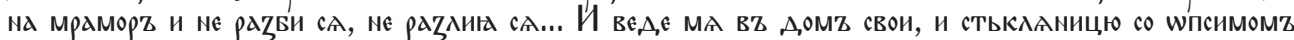

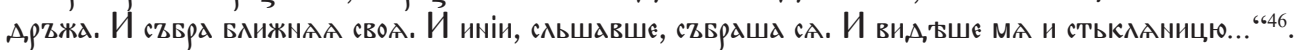
Within the macro-composition that vessel is mentioned again in the Second miracle in connection with the use of stored therein drink: ,...и ре: Аџє погаміи с8ть творили шпсимz сіи, ко ты

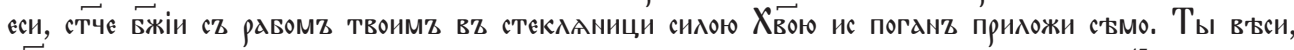

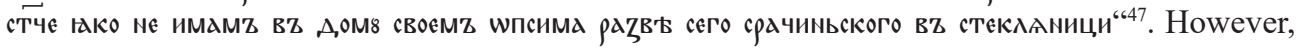
it is necessary to emphasize that the information on the use of glass vessels does not exceed the initial fragments and can be interpreted as influence of the compiled primary sources. The lack of notifications about glassware at home - writer's parts (miracles from Fourth to Tenth) of the macro-composition adds an additional contrast. It is difficult though to accept unreservedly that this fact is a reflection of elements of the environment and everyday life of the author, or to argue that this type of craft production is unnecessary luxury for the residents of the Bulgarian state in $9^{\text {th }}-10^{\text {th }}$ century, known through second-hand information, not personal impressions.

Quite different is the case with the produced from metal objects that are registered in almost all miracle stories of the cycle. This of course does not cause any surprise, bearing in mind the fact that the work is about miracles and signs performed by using the iron cross. Explicit mention of the material from which the miraculous item is made is found in the third story - About

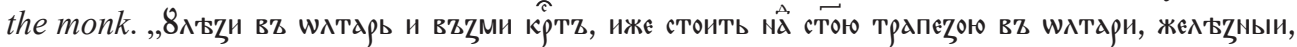
и, и и положи вратв волномв на глав'ь...". The information is repeated in the final passages of that

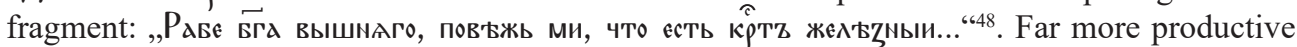
in a similar direction, however, are the Fourth and Fifth miracles. There the origin of the metal is clarified and also the important for the medieval life craft of the blacksmithing is underlined. 
Understandably, given the importance of blacksmithing, the notice of its practice attracts the

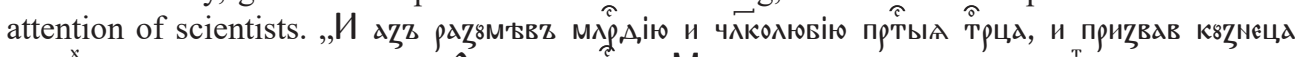

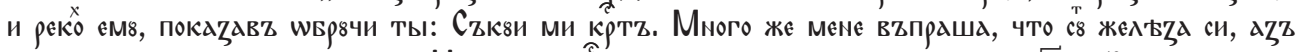

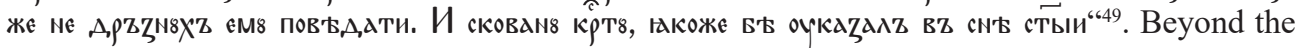
mentioned nonprofit - symbolic side - and the distinction of "dedicated - non-dedicated" in these fragments of the macro-composition, the passage indicates the presence of such craftsmen outside the capital and their work on order, with materials supplied by those ordering the finished product. Without surprise or unexpectedly, along with other household items made of iron, two more metals are registered in the text - gold and silver. The first one is present once in the introductory part. The other one is referred to in the three silver coins received from the thieving pastor for the sold lamb in the designated situation in the Seventh miracle. ${ }^{50}$

In this line of listing specifics and peculiarities of the environment in which the medieval author works, it should be mentioned that interest is also drawn by the double indication of the marble flooring within the cycle. Before deploying any comments about the residential architecture and decoration of homes, it is necessary to emphasize that the data of the macro-composition refer to a specific type of buildings. The marble, which is mentioned in the first and third stories, refers to the pavement on church floors. The circumstance in question is the essence of the opinion that the sole basis of these updates cannot be sufficient to say anything more than what is already known about its practical and functional aspects. What is more important to point out in this presentation is that the vague references to some elements of daily life such as food, beverages, household goods and raw materials, as well as the black-and-white world of the Tale of the Iron Cross is hardly due to any creative weakness. It is rather the result of personal aesthetic and artistic attitudes of the compiler of today's familiar version of the Old Bulgarian cycle of miracle stories.

Finally, the short announcement of the Tale's data, which concerned aspects of everyday life and the approaches applied above have been limited mainly to some moments which have been uninvestigated and unstudied properly until now. Due to objective reasons, the complete establishment of the prototexts has stayed out of the scope of the present paper as well as a critical juxtaposition of the texts. In this context, the current activity can be considered as the beginning of the establishment of the Tale of the Iron Cross as a trustworthy source of historical data from the late $9^{\text {th }}$ and the early $10^{\text {th }}$ century, but it cannot be considered as a completed stage.

${ }^{1}$ Cf.: Строев П. М. Рукописи славянские и российские, принадлежащие почетному гражданину и Археографической комиссии корреспонденту Ивану Никитичу Царскому. Разобраны и описаны Павлом Строевым. Москва, 1848. С. 768 (№ 717), С. 781 (№ 728); Архимандрит Леонид. Систематическое описание славянорусских рукописей собрания графа А. С. Уварова. Ч. 4. Москва, 1894. C. 45 (№ 1783).

2 Ангелов Б. Сказание за железния кръст. // Старобългарска литература. Кн. 1. 1971. С. 121-155; Ангелов Б. Сказание за железния кръст. // Ангелов Б. Ст. Из старата българска, руска и сръбска литература. Кн. III. София, 1978. С. 61-78; Моллов Т. Археография на Сказание за железния кръст и на отделните чудеса от него. // Калоянов А., Спасова М., Моллов Т. „Сказание за железния кръст“ и епохата на цар Симеон. Велико Търново, 2007. С. 218-223.

${ }^{3}$ Enископ Филарет Рижский. Кирилл и Мефодий, славянские просветители. // Чтения в Обществе истории и древностей российских. 1846. № 4. С. 5, б. 10; Епископ Евгений Астраханский. Внешнее состояние церкви Восточной Православной, с половины IX-го века до начало XIII-го // Християнское чтение. 1848. № 1. С. 249-250; Бодянский О. О времени происхождения славянских письмен. Москва, 1855. С. 357-358, CXIV-CXV; Палаузов С. Век болгарского царя Симеона. СанктПетербург, 1852. С. 23, б. 34; Голубинский Е. Краткий очерк истории православных церквей. Болгарской, сербской и румынской или молдо-валашской. - Москва, 1871. С. 34; С. 256, б. 63; Лопарев Хр. М. «Чудо святого Георгия о болгарине» // Памятники древней письменности. Т. 100. СанктПетербург, 1894. 24 с.; Дринов М. Исторически преглед на Българската църква от самото ѝ начало до днес // М. Дринов. Избрани съчинения. Т. 2. София, 1971. С. 34, б. 23. 
${ }^{4}$ Cf. with the designated bibliography: Tурилов A. Византийский и славянский пласты в «Сказании инока Христодула» (к вопросу о произхождении памятника) // Славяне и их соседи. Греческий и славянский мир в Средние века и раннее Новое время. Вып. 6. Москва, 1996. С. 8198; Стойкова A. Произведенията за св. Георги в балканските кирилски ръкописи (Предварителни бележки) // България и Сърбия в контекста на византийската цивилизация. Сборник статии от българо-сръбския симпозиум 14-16 септември 2003 / В. Гюзелев, А. Милтенова, Р. Станкова. София, 2005. С. 413-422; Петканова Д. Старобългарска литература IX-XVIII век. София, 1997. C. 349-351; Калоянов А., Спасова М., Моллов T. „Сказание за железния кръст“ и епохата на цар Симеон. Велико Търново, 2007. 224 с.; История на българската средновековна литература / Милтенова А. (съст.). София, 2008. С. 30, 140-141; Христов Я. Щрихи към „Сказание за железния кръст“. Благоевград, 2012. С. 5-20.

${ }^{5}$ Турилов A. «Сказание о железном кресте» как источник по истории и общественно-политической мысли Болгарии конца IX - начала X вв. // Идеология и общественно-политическая мысль в странах Центральной и Юговосточной Европы в период Средневековья: Сборник материалов и тезисов IV чтений памяти В. Д. Королюка. Москва, 1986. С. 36-37; Турилов А. Данные «Сказания о железном кресте» о христианизации Болгарии // Введение христианства у народов Центральной и Восточной Европы. Крещение Руси: Сборник тезисов. Москва, 1987. С. 53-54; Турилов А. Новосибирский список «Сказания инока Христодула» // Общественное сознание, книжность, литература периода феодализма. Новосибирск, 1990. С. 220-222; Турилов А. Византийский и славянский пласты в «Сказании инока Христодула» (к вопросу о произхождении памятника)... С. 81-99; Турилов А. К изучению «Сказания инока Христодула»: датировка цикла и имя автора // Florilegium. К 60-летию Б. Н. Флори: Сб. статей. Москва, 2000. С. 412-427; Турилов А. «Мъдра Пльсковская» и «Мъдра Дръсторская» - две Мундраги первой болгаро-венгерской войны (география чудес вмч. Георгия в Сказании инока Христодула) // Славяне и их соседы. Славяне и кочевой мир. Вып. 10. Москва, 2001. C. 40-58; Турилов A. «Не где князь живет, но вне» (Болгарское общество конца IX века в «Сказании о железном кресте») // Славяноведение. 2005. № 2. С. 20-27.

${ }^{6}$ Турилов А. Византийский и славянский пласты... С. 90-93; Турилов А. Данные «Сказания о железном кресте» о христианизации Болгарии... С. 54.

7 Божилов И. Културата на Средновековна България. София, 1993. С. 30-32; История на българската средновековна литература / Милтенова А. (съст.). С. 81-82.

${ }^{8}$ Христов Я. За болестите и лечителските практики в старобългарския цикъл разкази «Сказание за железния кръст»// Историческо бъдеще. 2011. № 1-2. С. 178-191. Quite recently, during the $23^{\text {rd }}$ International congress of Byzantine studies (Belgrade, August 22-27, 2016) the importance of the Tale's data was shown. There was a particular discussion on the paper Some features of everyday life in Slavia Orthodoxa at the beginning of the $10^{\text {th }}$ century. (According to the Old Bulgarian hagiographical cycle "A Tale of the Iron Cross") presented by Yanko Hristov and Nikolay Hrissimov in the Round table on Hagiography (part 3).

${ }^{9}$ Ангелов Б. Сказание за железния кръст... С. 146.

10 Даль В. Толковый словарь живаго великорускаго языка. T. IV. Санкт-Петербург-Москва, 1882. С. 498; Миклошич Ф., Востоков А. Х., Бередников Я. И., Кочетов И. С. Словарь древнего славянскаго языка составленный по Остромирову евангелию. Санкт-Петербург, 1899. С. 879. Срезневский И. И. Материалы для словаря древне-русскаго языка по письменнымъ памятникамъ. T. III. Санкт-Петербург, 1912. С. 1188-1189; Фасмер М. Этимологический словарь русского языка. T. IV. Москва, 1987. С. 157; Благова Э., Цейтлин Р. М., Вечерка Р. Старословянский словарь. (По рукописям X-XI веков). Москва, 1994. С. 733.

11 Архимандрит Киприан (Керн). Евхаристия. URL: http://azbyka.ru/otechnik/books/download/ 11665-evharistija.pdf (дата обращения: 27.09.16).

${ }^{12}$ Liddell H. G., R. Scott. A Greek-English Lexicon. Eight edition. New York-Chicago-Cincinnati, 1901. Р. 604; Срезневский И. И. Материалы... С. 1188; Иванова-Мирчева Д., Давидков А., Икономова Ж. Старобългарски речник. Т. 2. София 2009. С. 1055.

${ }_{13}$ Ангелов Б. Сказание за железния кръст... С. 139.

${ }^{14}$ Ангелов Б. Сказание за железния кръст... С. 136-139.

15 Пак там. С. 136-155.

${ }^{16}$ Снегаров И. Старобългарският разказ „Чудо на св. Георги с българина“ като исторически извор // Годишник на Духовната Академия „Св. Климент Охридски“. Т. 4 (XXX). 1954-1955. № 2. С. 225.

${ }_{17}$ Ангелов Б. Сказание за железния кръст... С. 142.

18 Ангелов Б. Сказание за железния кръст... С. 136-155. About the similarities and differences in a common European plan see: Adamson M. W. Food in Medieval Times. Westport-London, 2004. 258 p.; Fossier R. The Axe and the Oath. Ordinary Life in the Middle Ages. Princeton-Oxford, 2010. P. 59-67.

${ }^{19}$ Ангелов Б. Сказание за железния кръст... С. 142.

20 Барабанов H. Благочестивые заклания. Традиции публичных жертвоприношений в византийском приходском православии // Византийский временник. 2004. Т. 63 (88). С. 89-113; Драгова Н. Старобългарска култура. София, 2005. С. 176-183; Моллов Т. Българските и византий- 
ските чудеса на свети Георги (Текст и контекст в културата и историята) // Калоянов А., Спасова М., Моллов Т. „Сказание за железния кръст“ и епохата... С. 68-122.

21 Драгова Н. Старобългарска култура... С. 176-183.

${ }_{22}^{2}$ Ангелов Б. Сказание за железния кръст... С. 148.

${ }_{23}^{23}$ Драгова Н. Старобългарска култура... С. 181.

${ }^{24}$ Снегаров И. Старобългарският разказ „Чудо на св. Георги с българина“.... С. 225-227.

${ }^{25}$ Моллов T. Фолклорно-митологични елементи в старобългарската литература: „Чудо на свети Георги с българина““// Палеобалканистика и старобългаристика. Първи есенни национални четения „Проф. Иван Гълъбов““. Велико Търново, 1995. С. 411-419; Моллов Т. Българските и византийските чудеса на свети Георги... С. 82.

${ }^{26}$ In this line of thought the existence of a certain gradation of victims in their level of being close to the human is emphasized. Моллов Т. Българските и византийските чудеса на свети Георги... С. 83-87.

${ }^{27}$ Cf. Ангелов Б. Сказание за железния кръст... С. 142, 147-151.

${ }^{28}$ Барабанов Н. Благочестивые заклания... С. 89-113; Petropoulou M-Z. Animal Sacrifice in Ancient Greek Religion, Judaism and Christianity, 100 BC to AD 200. Oxford: University Press, 2008. P. 207-289.

${ }^{29}$ Ангелов Б. Сказание за железния кръст... С. 142.

${ }^{30}$ Пак там.

${ }^{31}$ Спасова М. Езикови особености на „Сказание за железния кръст“ // Калоянов А., Спасова М., Моллов T. „Сказание за железния кръст“ и епохата ... С. 148.

${ }^{32}$ Ангелов Б. Сказание за железния кръст... С. 145.

${ }^{33}$ Пак там. С. $136-155$.

${ }^{34}$ Максимович $K . A$. Техника ранних славянских переводов с латыни (на материале пенитенциала «Заповеди святых отец») // Byzantinoslavica. 2006. Т. 64. Р. 125-152.

${ }^{35}$ Максимович К. А. Техника ранних... Р. 147.

${ }^{36}$ Ангелов Б. Сказание за железния кръст... С. 138.

${ }^{37}$ Ангелов Б. Сказание за железния кръст... С. 136-155.

${ }^{38}$ See: Хрисимов Н., Петров М. Данни за мъжкото облекло от периода на Първото българско царство // Дриновський збірник/Дриновски сборник. Т. V. Харків-София, 2012. С. 94-111.

39 Доде 3. В. Средневековый костюм народов Северного Кавказа. Москва, 2001. Табл. 2.

${ }^{40}$ Турилов А. «Сказание о железном кресте» как источник по истории... С. 36.

${ }^{41}$ Ангелов Б. Сказание за железния кръст... С. 146. Ангелов Б. Старославянски текстове: 1 . Нов препис на старобългарския разказ „Чудото с българина“; 2. Разказ за пастиря ухапан от змия // Известия на Института за българска литература. 1955. Кн. 3. С. 175.

${ }^{42}$ Ангелов Б. Старославянски текстове... С. 176.

${ }^{43}$ See with the attached bibliography: Витлянов C. Стопанският облик на столичните манастири през IX-X век. // Плиска-Преслав. Т. 7. София, 1995. С. 92-100; Атанасов Г. За хронологията и монашеската организация в скалните обители през Първото българско царство // Светогорска обител Зограф. Т. 3. София, 1999. С. 281-293; Попконстантинов К. Към въпроса за отшелническите практики в България през X век. Светият отец Антоний от Крепча и св. Йоан Рилски // Светогорска обител Зограф. Т. 3. София, 1999. С. 83-89; Костова Р. От мирския живот към монашеството. Къде е границата и кой я преминава в България през X в.? // Традиции и приемственост в България и на Балканите през средните векове. Велико Търново, 2003. С. 147-166; Костова Р. Скалният манастир при с. Крепча. Още един поглед към монашеските практики в България през X в. // Проф. дин Станчо Ваклинов и средновековната българска култура. Велико Търново, 2005. С. 289-301.

${ }_{44}$ Джсингов $Г$. За производството на стъкло в средновековна България // Археология. 1960. № 4. С. 1-8; Джингов Г. Средновековна стькларска работилница в Патлейна // Известия на Археологически институт. 1963. Кн. 16. С. 47-69; Дончева-Петкова Л., Златинова Ж. Стъкларска работилница край западната крепостна стена в Плиска // Археология. 1978. № 4. С. 37-48; Балабанов Т. За началото на стъклообработването и стьклопроизводството в Средновековна България // Преслав. Т. 3. Варна, 1983. C. $228-241$.

${ }^{45}$ Ангелов Б. Сказание за железния кръст... С. 137-138.

${ }^{46}$ Пак там. С. 138.

${ }^{47}$ Пак там. С. 139.

${ }^{48}$ Ангелов Б. Сказание за железния кръст... С. 140.

${ }^{49}$ Пак там. С. 143.

50 Христов Я. Отново за разказа „За пастира, ухапан от змия“ // Palaeobulgarica. 2010. № 2. C. $78-84$. 